\title{
Antifungal and Larvicidal Activities of Phlorotannins from Brown Seaweeds
}

\author{
Bertoka Fajar Surya Perwira Negara ${ }^{1,2}$ (D) Jae-Hak Sohn ${ }^{1,2}$, Jin-Soo Kim ${ }^{3, *}$ and Jae-Suk Choi ${ }^{1,2, *(D)}$ \\ 1 Seafood Research Center, Industry-Academic Cooperation Foundation, Silla University, 606, \\ Advanced Seafood Processing Complex, Wonyang-ro, Amnam-dong, Seo-gu, Busan 49277, Korea; \\ ftrnd12@silla.ac.kr (B.F.S.P.N.); jhsohn@silla.ac.kr (J.-H.S.) \\ 2 Department of Food Biotechnology, College of Medical and Life Sciences, Silla University, 140, \\ Baegyang-daero 700beon-gil, Sasang-gu, Busan 46958, Korea \\ 3 Department of Seafood and Aquaculture Science, Gyeongsang National University, 38 Cheondaegukchi-gil, \\ Tongyeong-si, Gyeongsangnam-do 53064, Korea \\ * Correspondence: jinsukim@gnu.ac.kr (J.-S.K.); jsc1008@silla.ac.kr (J.-S.C.); Tel.: +82-55-772-9146 (J.-S.K.); \\ $+82-51-248-7789$ (J.-S.C.)
}

Citation: Negara, B.F.S.P.; Sohn, J.-H.; Kim, J.-S.; Choi, J.-S. Antifungal and Larvicidal Activities of Phlorotannins from Brown Seaweeds. Mar. Drugs 2021, 19, 223. https://doi.org/ $10.3390 /$ md19040223

Academic Editor: Roland Ulber

Received: 22 March 2021

Accepted: 15 April 2021

Published: 16 April 2021

Publisher's Note: MDPI stays neutral with regard to jurisdictional claims in published maps and institutional affiliations.

Copyright: (c) 2021 by the authors. Licensee MDPI, Basel, Switzerland. This article is an open access article distributed under the terms and conditions of the Creative Commons Attribution (CC BY) license (https:/ / creativecommons.org/licenses/by/ $4.0 /)$.

\begin{abstract}
Phlorotannins are secondary metabolites produced by brown seaweeds with antiviral, antibacterial, antifungal, and larvicidal activities. Phlorotannins' structures are formed by dibenzodioxin, ether and phenyl, ether, or phenyl linkages. The polymerization of phlorotannins is used to classify and characterize. The structural diversity of phlorotannins grows as polymerization increases. They have been characterized extensively with respect to chemical properties and functionality. However, review papers of the biological activities of phlorotannins have focused on their antibacterial and antiviral effects, and reviews of their broad antifungal and larvicidal effects are lacking. Accordingly, evidence for the effectiveness of phlorotannins as antifungal and larvicidal agents is discussed in this review. Online databases (ScienceDirect, PubMed, MEDLINE, and Web of Science) were used to identify relevant articles. In total, 11 articles were retrieved after duplicates were removed and exclusion criteria were applied. Phlorotannins from brown seaweeds show antifungal activity against dermal and plant fungi, and larvicidal activity against mosquitos and marine invertebrate larvae. However, further studies of the biological activity of phlorotannins against fungal and parasitic infections in aquaculture fish, livestock, and companion animals are needed for systematic analyses of their effectiveness. The research described in this review emphasizes the potential applications of phlorotannins as pharmaceutical, functional food, pesticide, and antifouling agents.
\end{abstract}

Keywords: phlorotannins; antifungal; larvicidal; brown seaweeds; biological activities

\section{Introduction}

Seaweeds are abundant in coastal regions and have become valuable sources of biologically active compounds and secondary metabolites, such as agar, carrageenan, alginate, alkaloids, phenolics, and phlorotannins, with extensive practical applications [1]. Phlorotannins are highly hydrophilic compounds formed by the acetate-malonate pathway. They contain phloroglucinol (Figure 1) (1,3,5-tryhydroxybenzene) units and have molecular sizes of $126 \mathrm{Da}-650 \mathrm{kDa}$ [2].

Ishige okamurae, Ecklonia cava, E. kurome, E. stolonifera, Pelvetia siliquosa, Eisenia arborea, and E. bicyclis as well as species in the genera Cystophora and Fucus have been reported to contain phlorotannins. Purified phlorotannins from these brown algae have antioxidant, antitumor, anticancer, anti-inflammatory, antiviral, antimicrobial, antifungal, and larvicidal activities, which are beneficial properties for the development of new functional agents [3-7]. 


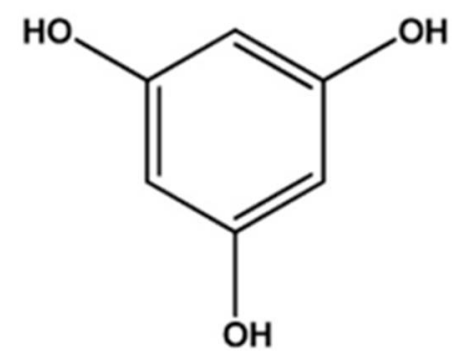

Figure 1. The basic structure of phlorotannins isolated from brown seaweeds [3].

Increasing antibiotic resistance and the spread of new variants of viruses are growing global problems [8]. Additionally, increases in mosquito larvae causing malaria, dengue hemorrhagic fever, filariasis, and chikungunya as well as biofouling marine invertebrate larvae have become major issues. Accordingly, the search for novel natural compounds to resolve these issues has been a major focus of research. Bioactive phlorotannins derived from brown algae have promising pharmacological and inhibitory effects [5,9-13] and, as described previously $[10,14-16]$, may be valuable compounds for resolving these growing issues.

The five review papers on biological activities of phlorotannins reported by Eom et al. [5] focused on the antimicrobial activity of phlorotannins. Besednova et al. [17] and Zaporozhets and Besednova [18] have reviewed antiviral activities of phlorotannins. Nonetheless, reviews of their other biological activities, such as antifungal and larvicidal activities, are lacking. Accordingly, this review provides a comprehensive overview of antifungal and larvicidal activities of phlorotannins, providing a strong basis for their development as new functional agents. The biological activities of phlorotannins further support the utility of brown seaweeds as sources of novel functional agents derived from natural compounds.

\section{Phlorotannins}

Phlorotannins are produced and found in physodes, which are located in cells' periphery and perinuclear regions [19]. Phlorotannins belong to phloroglucinol's oligomers that can act as both primary and secondary metabolites. They are only found in brown seaweed and formed by the acetate-malonate (polyketide) pathway in the Golgi apparatus [20]. A combination of ether and phenyl, ether, dibenzodioxin, or phenyl linkages form the structures of phlorotannins (Figure 2). As a result, based on the structural linkage, phlorotannins can be divided into six groups. Eckols contain dibenzo-1,4-dioxin linkages, carmalols contain dibenzodioxin moiety, fucols contain aryl-aryl bonds, phloretols contain aryl-ether bonds, fucophloretols contain ether or phenyl linage, and fuhalols contain ortho-/para-arranged ether bridges containing an additional hydroxyl group on one unit [21].

Phlorotannins have been isolated from brown seaweed such as Ecklonia cava, E. stolonifera, Sargassum ringgoldianum, Ishige okamurae, Fucus vesiculosus, and Eisenia bicyclis, as well as species in the genera Cystophora and Fucus. Eckol, phloroglucinol, dieckol, diphlorethohydroxycarmalol, 6,6'-bieckol, phlorofucofuroeckol A, dioxinodehydroeckol, and 7-phloroeckol have been extracted from these seaweeds. Table 1 summarize the phlorotannins that were extracted from brown seaweeds. 


\section{Ether linkages}<smiles>Oc1cc(O)cc(Oc2c(O)cc(O)cc2O)c1</smiles>

Diphlorethol<smiles>Oc1cc(O)c(Oc2cc(O)c(O)c(O)c2)c(O)c1</smiles>

Bifuhalol<smiles>Oc1cc(O)c(Oc2cc(O)c(Oc3cc(O)c(O)c(O)c3)c(O)c2Oc2cc(O)c(O)c(O)c2)c(O)c1</smiles>

Trifuhalol C

\section{Phenyl linkages}<smiles>Oc1cc(O)c(-c2c(O)cc(O)cc2O)c(O)c1</smiles>

Difucol<smiles>Oc1cc(O)c(-c2c(O)cc(O)c(-c3c(O)cc(O)cc3O)c2O)c(O)c1</smiles>

Trifucol

Ether and phenyl linkages<smiles>Oc1cc(O)c(Oc2cc(O)c(-c3c(O)cc(O)cc3O)c(O)c2)c(O)c1</smiles>

Fucophlorethol A<smiles>Oc1cc(O)cc(Oc2c(O)cc(O)c(-c3c(O)cc(O)cc3O)c2O)c1</smiles>

Fucophlorethol B

\section{Dibenzodioxin linkages}<smiles>Oc1cc(O)cc(Oc2c(O)cc(O)c3c2Oc2cc(O)cc(O)c2O3)c1</smiles>

Eckol<smiles>Oc1cc(O)c(Oc2cc3c(c(O)c2O)Oc2cc(O)c(Oc4cc(O)c(O)c(O)c4)c(O)c2O3)c(O)c1</smiles>

Diphlorethohydroxycarmanol

Figure 2. Structure of phlorotannins contain ether and phenyl-, ether-, dibenzodioxin-, or phenyl-linkages [22]. 
Table 1. Phlorothannin compounds extracted from brown seaweeds.

\begin{tabular}{|c|c|c|}
\hline Brown Seaweed & Compound & Ref. \\
\hline \multirow{3}{*}{ Ecklonia cava } & Eckol & [19-21] \\
\hline & Phloroglucinol & [20-23] \\
\hline & Dieckol & {$[20,21]$} \\
\hline \multirow{3}{*}{ Ecklonia stolonifera } & Phlorofucofuroeckol A & \multirow{3}{*}[24]{} \\
\hline & Dieckol & \\
\hline & Dioxinodehydroeckol & \\
\hline \multirow{5}{*}{ Eisenia bicyclis } & Phloroglucinol & \multirow{5}{*}{ [25] } \\
\hline & Eckol & \\
\hline & 7-phloroeckol & \\
\hline & Phlorofucofuroeckol A & \\
\hline & Dioxinodehydroeckol & \\
\hline Sargassum ringgoldianum & Phlorotannins extract & [26] \\
\hline \multirow{3}{*}{ Ishige okamurae } & Phloroglucinol & \multirow{3}{*}{ [27] } \\
\hline & Diphlorethohydroxycarmalol & \\
\hline & 6,6'-bieckol & \\
\hline Fucus vesiculosus & Phlorotannins extract & [28] \\
\hline
\end{tabular}

\section{Antifungal Activity of Phlorotannins}

The antifungal activity of phlorotannins has been evaluated by Kim et al. [29], Lopes et al. [30], Lee et al. [31], and Corato et al. [32]. These studies have reported the antifungal activity of phlorotannins against dermal fungi, such as Candida albicans, Epidermophyton floccosum, Trichophyton rubrum, and Trichophyton mentagrophytes, and plant fungi, such as Botrytis cinerea and Monilinia laxa, as summarized in Table 2.

Table 2. Antifungal activities of phlorotannins extracted from brown seaweeds.

\begin{tabular}{|c|c|c|c|c|}
\hline Fungi & Extract/Chemical & Source & Activities & Ref. \\
\hline \multicolumn{5}{|c|}{ Dermal fungi } \\
\hline Candida albicans & Fucofuroeckol-A & Eisenia bicyclis & $\mathrm{MIC}^{\mathrm{a}}$ of $512 \mu \mathrm{g} / \mathrm{mL}$ & [29] \\
\hline Candida albicans & \multirow{12}{*}{ Phlorotannins extract } & Cystoseira nodicaulis & $\mathrm{MIC}$ of $15.6 \mathrm{mg} / \mathrm{mL}$ & \multirow{12}{*}[30]{} \\
\hline Candida albicans & & Crassiphycus usneoides & $\mathrm{MIC}$ of $31.3 \mathrm{mg} / \mathrm{mL}$ & \\
\hline Candida albicans & & Fucus spiralis & $\mathrm{MIC}$ of $31.3 \mathrm{mg} / \mathrm{mL}$ & \\
\hline Epidermophyton floccosum & & Cystoseira nodicaulis & $\mathrm{MIC}$ of $3.9 \mathrm{mg} / \mathrm{mL}$ & \\
\hline Epidermophyton floccosum & & Crassiphycus usneoides & $\mathrm{MIC}$ of $15.6 \mathrm{mg} / \mathrm{mL}$ & \\
\hline Epidermophyton floccosum & & Fucus spiralis & $\mathrm{MIC}$ of $7.8 \mathrm{mg} / \mathrm{mL}$ & \\
\hline Trichophyton rubrum & & Cystoseira nodicaulis & $\mathrm{MIC}$ of $3.9 \mathrm{mg} / \mathrm{mL}$ & \\
\hline Trichophyton rubrum & & Crassiphycus usneoides & $\mathrm{MIC}$ of $15.6 \mathrm{mg} / \mathrm{mL}$ & \\
\hline Trichophyton rubrum & & Fucus spiralis & $\mathrm{MIC}$ of $3.9 \mathrm{mg} / \mathrm{mL}$ & \\
\hline Trichophyton mentagrophytes & & Cystoseira nodicaulis & $\mathrm{MIC}$ of $7.8 \mathrm{mg} / \mathrm{mL}$ & \\
\hline Trichophyton mentagrophytes & & Crassiphycus usneoides & $\mathrm{MIC}$ of $31.3 \mathrm{mg} / \mathrm{mL}$ & \\
\hline Trichophyton mentagrophytes & & Fucus spiralis & $\mathrm{MIC}$ of $15.6 \mathrm{mg} / \mathrm{mL}$ & \\
\hline Trichophyton rubrum & Dieckol & Ecklonia cava & MIC of $200 \mu \mathrm{M}$ & [31] \\
\hline
\end{tabular}


Table 2. Cont.

\begin{tabular}{|c|c|c|c|c|}
\hline Fungi & Extract/Chemical & Source & Activities & Ref. \\
\hline \multicolumn{5}{|c|}{ Plant fungi } \\
\hline \multirow{2}{*}{ Botrytis cinerea } & Phlorethols & \multirow{4}{*}{ Laminaria digitata } & \multirow{4}{*}{ MGI $^{\mathrm{b}}$ of $100 \%$} & \multirow{4}{*}[32]{} \\
\hline & Fucophloretols & & & \\
\hline \multirow{2}{*}{ Monilinia laxa } & Phlorethols & & & \\
\hline & Fucophloretols & & & \\
\hline
\end{tabular}

${ }^{a}$ MIC: Minimum inhibitory concentration. ${ }^{\mathrm{b}}$ MGI: Mycelia growth inhibition.

The effects of phlorotannins against dermal fungal pathogens have been evaluated. Lopes et al. [30] extracted phlorotannins from Cystoseira nodicaulis, Crassiphycus usneoides, and Fucus spiralis using $n$-hexane and then extracted using acetone:water (7:3). These phlorotannins exhibit antifungal activity against $C$. albicans, E. floccosum, and T. mentagrophytes. The MIC values of phlorotannins against these fungi range from 3.9 to $31.3 \mathrm{mg} / \mathrm{mL}$. Fucofuroeckol-A, isolated from Eisenia bicyclis, and dieckol, isolated from Ecklonia cava, have antifungal activities $[29,31]$. Fucofuroeckol-A shows an MIC of $512 \mu \mathrm{g} / \mathrm{mL}$ against $C$. albicans [29], whereas dieckol exhibits a MIC of $200 \mu \mathrm{M}$ against Trichophyton rubrum [31]. Although dieckol has shown antifungal activity, the concentration was extremely high. A general lack of selectivity of new drugs candidate should have $>50 \%$ inhibition at a concentration less than $30 \mu \mathrm{M}$ [33]. Corato et al. [32] have shown that phlorethols and fucophloretols extracted from Laminaria digitata are effective against plant fungal pathogens, such as B. cinerea and M. laxa, with $100 \%$ mycelial growth inhibition.

In fungal cell, phlorotannins block dimorphic complexes, resulting in the appearance of pseudohyphae with decreasing surface adhesive properties. The virulence and capacity to invade fungal host cells are also decreased by phlorotannins. On the other hand, phlorotannins induced reactive oxygen species (ROS) production and triggered early apoptosis, resulting in the activation of the CaMCA1 gene (Metacaspase 1) and membrane disruption. These inhibitory effects promote phlorotannins as new antifungal agents $[29,30,32]$.

The effectiveness of phlorotannins as antifungal agents depends on numerous factors, such as the complex interactions between chemical compounds and the host and rates of degradation, hydrolysis, and polymerization. In the first step of nature compound discovery as new drug candidate, MICs are usually the starting point for larger preclinical evaluations of novel drug agents, and to ensure that compounds efficiently increase the success of treatment [31,32].

Increased rates of fungal infections in humans, animals, and plants necessitate the development of new antifungal agents. The antifungal effects of phlorotannin extracts, phlorethols, fucophloretols, fucofuroeckol-A, and dieckol have been evaluated. However, other subclasses of phlorotannins remain to be explored and should be a focus of further research aimed at the identification of novel antifungals.

\section{Larvicidal Activity of Phlorotannins}

The larvicidal activity of phlorotannins has been reported by Thangam and Kathiresan [34], Ravikumar et al. [35], Manilal et al. [36], Birrell et al. [37], Brock et al. [38], Lau and Qian [39], and Tsukamoto et al. [40]. These studies evaluated effects against mosquito larvae, such as Aedes aegypti and Culex quinquefasciatus, and against marine invertebrate larvae, such as Acropora millepora, Balanus improvises, Hydroides elegans, Halocynthia roretzi, and Ciona savignyi, as summarized in Table 3. 
Table 3. Larvicidal activities of phlorotannins extracted from brown seaweeds.

\begin{tabular}{|c|c|c|c|c|}
\hline Larvae & Extract/Chemical & Sources & Activities & Ref. \\
\hline \multicolumn{5}{|c|}{ Mosquitos } \\
\hline Aedes aegypti & Phlorotannins extract & Dictyota dichotoma & $\mathrm{LC}_{50}{ }^{\mathrm{a}}$ of $61.66 \mathrm{mg} / \mathrm{L}$ & [34] \\
\hline Aedes aegypti & Phlorotannins extract & Dictyota dichotoma & $\mathrm{LC}_{50}$ of $0.0683 \mu \mathrm{g} / \mathrm{mL}$ & [35] \\
\hline Aedes aegypti & \multirow{6}{*}{ Phlorotannins extract } & Lobophora variegata & $\mathrm{LC}_{50}$ of $70.38 \mu \mathrm{g} / \mathrm{mL}$ & \multirow{6}{*}{ [36] } \\
\hline Aedesaegypti & & Stoechospermum marginatum & $\mathrm{LC}_{50}$ of $82.95 \mu \mathrm{g} / \mathrm{mL}$ & \\
\hline Aedesaegypti & & Sargassum wightii & $\mathrm{LC}_{50}$ of $84.82 \mu \mathrm{g} / \mathrm{mL}$ & \\
\hline Culex quinquefasciatus & & Lobophora variegata & $\mathrm{LC}_{50}$ of $79.43 \mu \mathrm{g} / \mathrm{mL}$ & \\
\hline Culex quinquefasciatus & & Stoechospermum marginatum & $\mathrm{LC}_{50}$ of $85.11 \mu \mathrm{g} / \mathrm{mL}$ & \\
\hline Culex quinquefasciatus & & Sargassum wightii & $\mathrm{LC}_{50}$ of $87.09 \mu \mathrm{g} / \mathrm{mL}$ & \\
\hline \multicolumn{5}{|c|}{ Marine invertebrate } \\
\hline Acropora millepora & Phlorotannins extract & Padina sp. & $\begin{array}{c}30 \% \text { of coral settlement } \\
\text { was reduced }\end{array}$ & [37] \\
\hline Balanus improvisus & Phlorotannins extract & Fucus vesiculosus & $\begin{array}{c}\text { Larvae settlement was } \\
\text { deterred at } 31.5 \mu \mathrm{g} / \mathrm{mL} \\
\text { of concentration }\end{array}$ & [38] \\
\hline Hydroides elegans & Phlorotannins extract & Sargassum tenerrimum & $\mathrm{LC}_{50}$ of $13.98 \mu \mathrm{g} / \mathrm{mL}$ & [39] \\
\hline Ciona savignyi & \multirow{2}{*}{ Phlorotannins extract } & \multirow{2}{*}{ Sargassum thunbergii } & $\begin{array}{c}33 \% \text { of larval } \\
\text { metamorphosis were } \\
\text { inhibited at } 25 \mu \mathrm{g} / \mathrm{mL}\end{array}$ & \multirow[t]{2}{*}{ [40] } \\
\hline Halocynthia roretzi & & & $\begin{array}{l}27 \% \text { of larval } \\
\text { metamorphosis were } \\
\text { inhibited at } 25 \mu \mathrm{g} / \mathrm{mL}\end{array}$ & \\
\hline
\end{tabular}

\footnotetext{
${ }^{\mathrm{a}} \mathrm{LC}_{50}$ : Lethal concentration.
}

Phlorotannins show potential activity against mosquito larvae. Thangam and Kathiresan [34], Ravikumar et al. [35], and Manilal et al. [36] have reported that phlorotannins extracted from brown seaweeds, such as Dictyota dichotoma, Lobophora variegata, Stoechospermum marginatum, and Sargassum wightii, exhibit $\mathrm{LC}_{50}$ values ranging from 0.0683 to $85.11 \mu \mathrm{g} / \mathrm{mL}$ against mosquito larvae-namely, A. aegypti and C. quinquefasciatus.

Birrell et al. [37] reported that phlorotannins from Padina sp. reduce the settlement of Acropora millepora larvae by $30 \%$. Furthermore, phlorotannins from Fucus vesiculosus inhibit the larval settlement of Balanus improvises [38].

Study by Lau and Qian [39] reported that phlorotannins extract from Sargassum tenerrimum showed larvicidal activity in Hydroides elegans with an $\mathrm{LC}_{50}$ of $13.98 \mu \mathrm{g} / \mathrm{mL}$. Tsukamoto et al. [40] demonstrated that phlorotannins extract inhibit $33 \%$ and $27 \%$ larval metamorphosis of Ciona savignyi and Halocynthia roretzi at low concentrations $(25 \mu \mathrm{g} / \mathrm{mL})$.

In mosquito larvae, acute mortality and sublethality are the two main effects observed. With respect to sublethal effects, morphogenetic and external structural changes occur during the exposure period [41]. Other toxic effects, such as effects on growth, development, fecundity, fertility, and adult longevity in mosquitoes, have also been recorded [42,43]. Moreover, inhibitory effects on the cholinesterase enzymes cholinergic and gamma-aminobutyric acid (GABA) as well as mitochondrial and octopaminergic systems have also been recorded [44,45].

As larvae settlement inhibition agents, phlorotannins can influence the coral larval settlement process. In nature, phlorotannins delay the settlement process before larvae attach to substrates, even in areas free of macroalgae or with suitable substrates [37]. Furthermore, phlorotannins can inhibit settlement process of cyprids larvae. These findings indicate that phlorotannins from brown seaweeds might serve an essential ecological role as inhibitors of fouling. The larvicidal effects of phlorotannins might be mediated by various mechanisms, 
including the direct inhibition of the settlement and/or survival of larvae and regulation of the growth of bacterial microfoulers, affecting larval settlement. On the other hand, phlorotannins can quicken the metamorphosis of Ciona savignyi and Halocynthia roretzi compared to sulfoquinovosyl diacylglycerol at the same concentrations [40]. These findings suggest that phlorotannins can act as an antifouling agent without causing disruption to other organisms.

However, most studies of the larvicidal activity of phlorotannins have focused on crude phlorotannins. To the best of our knowledge, other subclasses of phlorotannins, such as fuhalols, phlorethols, fucols, and fucophloroethols, have not been tested. These phlorotannins have a wide range of biological activities and further studies should evaluate their larvicidal effects and underlying mechanisms.

\section{Extraction of Phlorotannins from Brown Seaweeds}

Solid-liquid extraction using organic solvents is the most common method for obtaining phlorotannins from brown seaweeds. Phlorotannins can be extracted using polar solvents, including acetone, ethanol, and methanol. A mixture of polar solvents and water is often used to extract phlorotannins [46-51]. During the extraction procedure, the temperature is set to no more than $52{ }^{\circ} \mathrm{C}$ (and commonly to room temperature) to minimize the degradation of polyphenolic compounds [46,47]. The amount of phlorotannins extracted depends on the type of seaweed and the solvent used. Table 4 show phlorotannin yields obtained using organic solvents. Extraction of phlorotannins using both methanol:water (60\%:40\%) and methanol yielded phlorotannins ranging from 2 to $370 \mathrm{mg} / \mathrm{g}$. Methanol solvent yielded the most phlorotannins but needs further processing to purify the compounds.

Table 4. Yield of phlorotannins extracted from brown seaweeds using organic solvent.

\begin{tabular}{|c|c|c|c|}
\hline Sources & Solvent & Yield & Ref. \\
\hline Ascophyllum nodosum & \multirow{5}{*}{ Methanol:Water (60\%:40\%) } & $2 \mathrm{mg} / \mathrm{g}$ & \multirow{5}{*}{ [52] } \\
\hline Fucus serratus & & $2.6 \mathrm{mg} / \mathrm{g}$ & \\
\hline Fucus vesiculosus & & $2.92 \mathrm{mg} / \mathrm{g}$ & \\
\hline Laminaria hyperborean & & $2.46 \mathrm{mg} / \mathrm{g}$ & \\
\hline Pelvetia canaliculata & & $2.2 \mathrm{mg} / \mathrm{g}$ & \\
\hline Ascophyllum nodosum & \multirow{2}{*}{ Methanol:Water (60\%:40\%) } & $6.66 \mathrm{mg} / \mathrm{g}$ & \multirow{2}{*}{ [53] } \\
\hline Himanthalia elongata & & $2.79 \mathrm{mg} / \mathrm{g}$ & \\
\hline Ecklonia kurome & Methanol & $370 \mathrm{mg} / \mathrm{g}$ & [54] \\
\hline Ishige okamurae & Methanol & $190 \mathrm{mg} / \mathrm{g}$ & [55] \\
\hline
\end{tabular}

Naturally, concentration of phlorotannins in brown seaweeds is affected by biological factors, such as the species, tissue type, size, and age, as well as environmental conditions, such as nutrient levels, water temperature, season, herbivore intensity, and light intensity $[46,47]$. The extraction method also affects the yield.

Although solid-liquid extraction has been used to obtain phlorotannins from brown seaweeds, this method has a number of weaknesses, such as long extraction times for high yields, a lack of specificity, and the need to purify the extract [46-48]. Supercritical fluid extraction, microwave extraction, liquid extraction under pressure, ultrasonic extraction, and enzymatic extraction are alternative methods for phlorotannins extraction. These methods can increase yield, increase purity, and reduce extraction times [47-49,51,56].

Enzymatic extraction offers high yield values by the destruction of the cell wall. Puspita et al. [51] obtained a higher phlorotannins yield from Sargassum polycystum by the enzymatic method (21-38\% phlorotannins) than by the solid solid-liquid method (3-15\%). Similar to the enzymatic extraction method, the ultrasonic extraction method enables a high yield by destroying cell walls using mass transfer during the process [48]. Furthermore, 
the low time requirement is the greatest advantage of high-pressure liquid extraction and microwave methods [46-49,51].

\section{Future Prospects for Phlorotannins}

Since phlorotannins possess many biological activities, these compounds have attracted substantial research attention. The high effectiveness and low toxicity of these compounds support their utilization as components of pharmaceuticals, cosmetics, and food products (Figure 3).

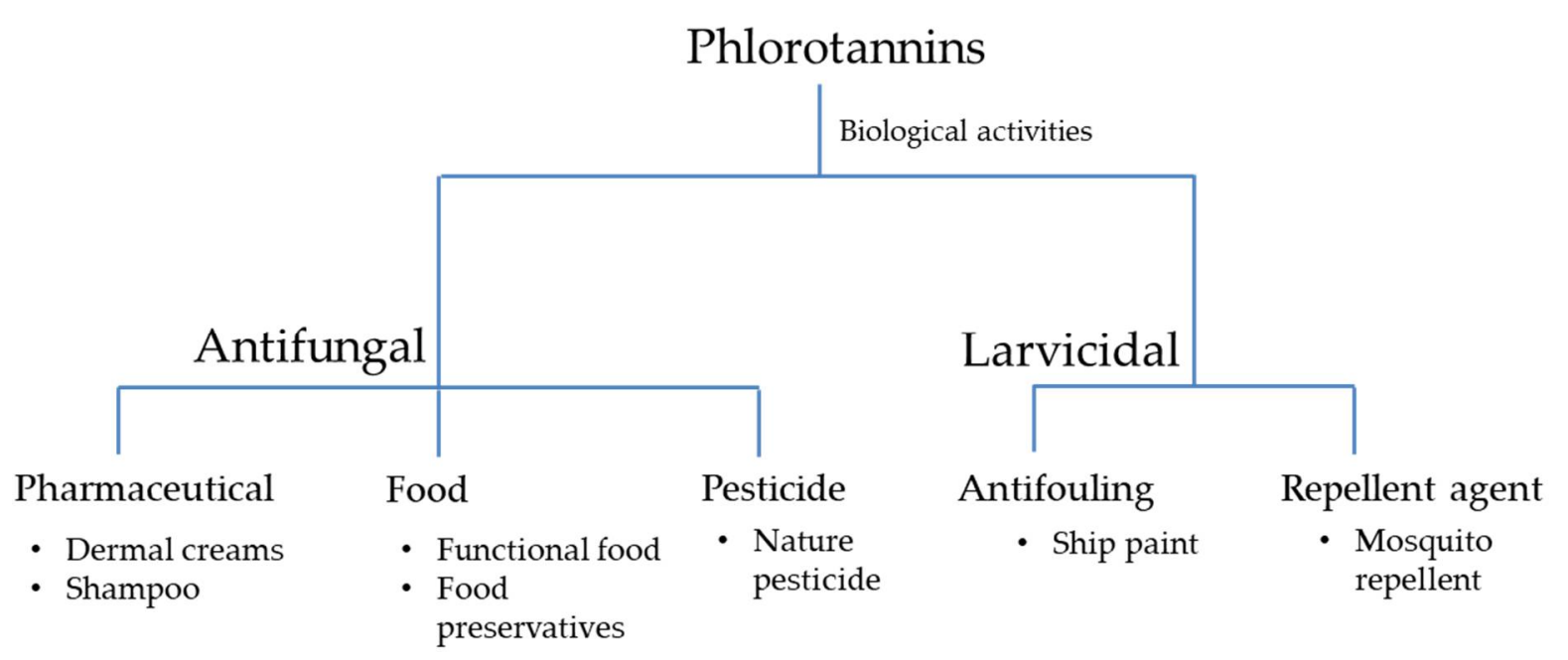

Figure 3. Application of phlorotannins as pharmaceutical, food, pesticide, antifouling, and repellent agents.

According to Paradis et al. [57], Baldrick et al. [58], and Shin et al. [59], no side effects of phlorotannins have been recorded after testing in humans. Negara et al. [60] further reported that phlorotannins exhibit biological activities with low toxic effects on humans and animals. Phlorotannins successfully decrease the incremental areas under the curve in plasma insulin, cholesterol (both low-density and high-density lipoprotein levels), DNA damage, body fat ratio, and waist/hip ratio. Um et al. [61] reported no serious side effects, such as nausea, mild fatigue, abdominal distension, and dizziness. Thus, phlorotannins are new candidates for applications as pharmaceutical, food, pesticide, antibiofouling, and repellent agents.

Kim et al. [29], Lopes et al. [30], and Lee et al. [31] have shown that phlorotannins exhibit antifungal activities against dermatophytic fungi, such as Candida albicans, Epidermophyton floccosum, Trichophyton rubrum, and Trichophyton mentagrophytes, which cause skin infections. Accordingly, phlorotannins are promising compounds for the development of dermal creams with antifungal effects. In addition, Corato et al. [32] reported that phlorotannins successfully inhibit the mycelia of plant fungal pathogens, suggesting that they are potentially new natural pesticides. In food, antifungal activities exhibited by phlorotannins could be developed as food preservatives.

The larvicidal activity of phlorotannins in mosquitos reported by Thangam and Kathiresan [34], Ravikumar et al. [35], and Manilal et al. [36] suggests that they may be effective mosquito repellent agents. Phlorotannins have shown effects against marine invertebrate larvae [37-40], suggesting that they are natural antifouling agents. Unlike heavy metals, which act as broad-spectrum toxins to both targeted and nontargeted marine organisms [62], the natural antifouling effects of phlorotannins showed specificity to the target organism.

Therefore, recent research clearly supports the use of phlorotannins as pharmaceutical, cosmetic, antifouling, and food preservation agents. However, in-depth studies of phlorotannins are needed to determine their precise effects. 


\section{Method}

Following Systematic Reviews and Meta-Analyses (PRISMA) guidelines, various online databases (Web of Science, ScienceDirect, MEDLINE, and PubMed) were used for literature searches [63]. "Phlorotannins OR antifungal OR larvicidal OR activity OR biological OR in vitro" was used as the search strategy. English language and effectiveness were applied as filters. In total, 85 articles were collected. After filtering, 11 articles were reviewed.

\section{Conclusions}

Our review revealed that phlorotannins from brown seaweeds exhibit activities against dermal and plant fungi, and mosquito and marine organism larvae. These findings provide a basis for the development of phlorotannins as new functional foods, feeds, pharmaceuticals, and larvicidal agents. To the best of our knowledge, their effects against viral, microbial, and parasitic infections have not been evaluated in fish, livestock, and companion animals; further studies on the biological activities of phlorotannins in these organisms are needed.

Author Contributions: Conceptualization, J.S.C.; methodology, B.F.S.P.N.; formal analysis, J.H.S.; data curation, J.H.S.; writing — original draft preparation, B.F.S.P.N.; writing—review and editing, J.-S.C.; visualization, J.-S.K.; supervision, J.-S.C., J.-S.K. All authors have read and agreed to the published version of the manuscript.

Funding: This study was funded by the Ministry of Oceans and Fisheries, Republic of Korea, under Project no. PJT201277.

Institutional Review Board Statement: Not applicable.

Conflicts of Interest: The authors declare no conflict of interest.

\section{References}

1. Arnold, T.M.; Targett, N.M. Quantifying in situ rates of phlorotannin synthesis and polymerization in marine brown algae. J. Chem. Ecol. 1998, 24, 577-595. [CrossRef]

2. Li, Y.X.; Wijesekara, I.; Li, Y.; Kim, S.K. Phlorotannins as bioactive agents from brown algae. Process Biochem. 2011, 46, $2219-2224$. [CrossRef]

3. Kang, M.C.; Cha, S.H.; Wijesinghe, W.A.J.P.; Kang, S.M.; Lee, S.H.; Kim, E.A.; Song, C.B.; Jeon, Y.J. Protective effect of marine algae phlorotannins against AAPH-induced oxidative stress in zebrafish embryo. Food Chem. 2013, 138, 950-955. [CrossRef] [PubMed]

4. Cha, J.Y.; Lee, B.J.; Je, J.Y.; Kang, Y.M.; Kim, Y.M.; Cho, Y.S. GABA-enriched fermented Laminaria japonica protects against alcoholic hepatotoxicity in sprague-dawley rats. Fish. Aquat. Sci. 2011, 14, 79-88. [CrossRef]

5. Eom, S.H.; Kim, Y.M.; Kim, S.K. Antimicrobial effect of phlorotannins from marine brown algae. Food Chem. Toxicol. 2012, 50, 3251-3255. [CrossRef]

6. Gupta, S.; Abu-Ghannam, N. Recent developments in the application of seaweeds or seaweed extracts as a means for enhancing the safety and quality attributes of foods. Innov. Food Sci. Emerg. Technol. 2011, 12, 600-609. [CrossRef]

7. Kim, K.H.; Yu, D.; Eom, S.H.; Kim, H.J.; Kim, D.H.; Song, H.S.; Kim, D.M.; Kim, Y.M. Fucofuroeckol-A from edible marine alga Eisenia bicyclis to restore antifungal activity of fluconazole against fluconazole-resistant Candida albicans. J. Appl. Phycol. 2018, 30, 605-609. [CrossRef]

8. Kaplan, S.L.; Mason, E.O. Management of infections due to antibiotic-resistant Streptococcus pneumonia. Clin. Microbiol. Rev. 1998, 11, 628-644. [CrossRef] [PubMed]

9. Choi, J.S.; Lee, K.; Lee, B.B.; Kim, Y.C.; Kim, Y.D.; Hong, Y.K.; Cho, K.K.; Choi, I.S. Antibacterial activity of the phlorotannins dieckol and phlorofucofuroeckol-a from Ecklonia cava against propionibacterium acnes. Bot. Sci. 2014, 92, 425-431. [CrossRef]

10. Lee, J.H.; Eom, S.H.; Lee, E.H.; Jung, Y.J.; Kim, H.J.; Jo, M.R.; Son, K.T.; Lee, H.J.; Kim, J.H.; Lee, M.S.; et al. In vitro antibacterial and synergistic effect of phlorotannins isolated from edible brown seaweed Eisenia bicyclis against acne-related bacteria. Algae 2014, 29, 47-55. [CrossRef]

11. Karadeniz, F.; Kang, K.H.; Park, J.W.; Park, S.J.; Kim, S.K. Anti-HIV-1 activity of phlorotannin derivative 8,4"-dieckol from korean brown alga Ecklonia cava. Biosci. Biotechnol. Biochem. 2014, 78, 1151-1158. [CrossRef]

12. Morán-Santibañez, K.; Peña-Hernández, M.A.; Cruz-Suárez, L.E.; Ricque-Marie, D.; Skouta, R.; Vasquez, A.H.; Rodríguez-Padilla, C.; Trejo-Avila, L.M. Virucidal and synergistic activity of polyphenol-rich extracts of seaweeds against measles virus. Viruses 2018, 10, 465. [CrossRef] [PubMed]

13. Park, J.Y.; Kim, J.H.; Kwon, J.M.; Kwon, H.J.; Jeong, H.J; Kim, Y.M.; Kim, D.; Lee, W.S.; Ryu, Y.B. Dieckol, a SARS-CoV 3CL(pro) inhibitor, isolated from the edible brown algae Ecklonia cava. Bioorg. Med. Chem. 2013, 21, 3730-3737. [CrossRef] 
14. Lopes, G.; Sousa, C.; Silva, L.R.; Pinto, E.; Andrade, P.B.; Bernardo, J.; Mouga, T.; Valentão, P. Can phlorotannins purified extracts constitute a novel pharmacological alternative for microbial infections with associated inflammatory conditions? PLOS ONE 2012, 7, e31145. [CrossRef]

15. Nagayama, K.; Iwamura, Y.; Shibata, T.; Hirayama, I.; Nakamura, T. Bactericidal activity of phlorotannins from the brown alga Ecklonia kurome. J. Antimicrob. Chemother. 2002, 50, 889-893. [CrossRef] [PubMed]

16. Wang, Y.; Xu, Z.; Bach, S.J.; McAllister, T.A. Sensitivity of Escherichia coli to seaweed (Ascophyllum nodosum) phlorotannins and terrestrial tannins. Asian-Australas. J. Anim. Sci. 2009, 22, 238-425. [CrossRef]

17. Besednova, N.N.; Andryukov, B.G.; Zaporozhets, T.S.; Kryzhanovsky, S.P.; Fedyanina, L.N.; Kuznetsova, T.A.; Zvyagintseva, T.N.; Shchelkanov, M.Y. Antiviral Effects of Polyphenols from Marine Algae. Biomedicines 2021, 9, 200. [CrossRef] [PubMed]

18. Zaporozhets, T.S.; Besednova, N.N. Biologically active compounds from marine organisms in the strategies for combating coronaviruses. AIMS Microbiol. 2020, 6, 470-494. [CrossRef]

19. Santos, S.A.O.; Félix, R.; Pais, A.C.S.; Rocha, S.M.; Silvestre, A.J.D. The quest for phenolic compounds from macroalgae: A review of extraction and identification methodologies. Biomolecules 2019, 9, 847. [CrossRef]

20. Stengel, D.B.; Connan, S.; Popper, Z.A. Algal chemodiversity and bioactivity: Sources of natural variability and implications for commercial application. Biotechnol. Adv. 2011, 29, 483-501. [CrossRef]

21. Heo, S.J.; Ko, S.C.; Cha, S.H.; Kang, D.H.; Park, H.S.; Choi, Y.U.; Kim, D.; Jung, W.-K.; Jeon, Y.J. Effect of phlorotannins isolated from Ecklonia cava on melanogenesis and their protective effect against photo-oxidative stress induced by UV-B radiation. Toxicol. In Vitro 2009, 23, 1123-1130. [CrossRef] [PubMed]

22. Arbenz, A.; Avérous, L. Chemical modification of tannins to elaborate aromatic biobased macromolecular architectures. Green Chem. 2015, 17, 2626-2646. [CrossRef]

23. Kang, K.A.; Lee, K.H.; Chae, S.; Zhang, R.; Jung, M.S.; Ham, Y.M.; Baik, J.S.; Lee, N.H.; Hyun, J.W. Cytoprotective effect of phloroglucinol on oxidative stress induced cell damage via catalase activation. J. Cell. Biochem. 2006, 97, 609-620. [CrossRef] [PubMed]

24. Kim, A.R.; Shin, T.S.; Lee, M.S.; Park, J.Y.; Park, K.E.; Yoon, N.Y.; Kim, J.S.; Choi, J.S.; Jang, B.C.; Byun, D.S.; et al. Isolation and identification of phlorotannins from Ecklonia stolonifera with antioxidant and anti-inflammatory properties. J. Agric. Food Chem. 2009, 57, 3483-3489. [CrossRef]

25. Jung, H.A.; Jin, S.E.; Ahn, B.R.; Lee, C.M.; Choi, J.S. Anti-inflammatory activity of edible brown alga Eisenia bicyclis and its constituents fucosterol and phlorotannins in LPS-stimulated RAW264.7 macrophages. Food Chem. Toxicol. 2013, 59, 199-206. [CrossRef]

26. Nakai, M.; Kageyama, N.; Nakahara, K.; Miki, W. Phlorotannins as radical scavengers from the extract of Sargassum ringgoldianum. Mar. Biotechnol. 2006, 8, 409-414. [CrossRef]

27. Cruces, E.; Huovinen, P.; Gómez, I. Interactive effects of UV radiation and enhanced temperature on photosynthesis, phlorotannin induction and antioxidant activities of two sub-Antarctic brown algae, Mar. Biol. 2013, 160, 1-13. [CrossRef]

28. Wang, T.; Jonsdottir, R.; Liu, H.; Gu, L.; Kristinsson, H.G.; Raghavan, S.; Olafsdottir, G. Antioxidant capacities of phlorotannins extracted from the brown algae Fucus vesiculosus. J. Agric. Food Chem. 2012, 60, 5874-5883. [CrossRef]

29. Kim, H.J.; Dasagrandhi, C.; Kim, S.H.; Kim, B.G.; Eom, S.H.; Kim, Y.M. In vitro antibacterial activity of phlorotannins from edible brown algae, Eisenia bicyclis against streptomycin-resistant Listeria monocytogenes. Indian J. Microbiol. 2018, 58, 105-108. [CrossRef]

30. Lopes, G.; Pinto, E.; Andrade, P.B.; Valentao, P. Antifungal activity of phlorotannins against dermatophytes and yeasts: Approaches to the mechanism of action and influence on Candida albicans virulence factor. PLoS ONE 2013, 8, e72203. [CrossRef]

31. Lee, M.H.; Lee, K.B.; Oh, S.M.; Lee, B.H.; Chee, H.Y. Antifungal Activities of Dieckol Isolated from the Marine Brown Alga Ecklonia cava against Trichophyton rubrum. J. Korean Soc. Appl. Biol. Chem. 2010, 53, 504-507. [CrossRef]

32. Coratoa, U.D.; Salimbenib, R.; Pretisb, A.D.; Avellab, N.; Patruno, G. Antifungal activity of crude extracts from brown and red seaweeds by a supercritical carbon dioxide technique against fruit postharvest fungal diseases. Postharvest Biol. Technol. 2017, 131, 16-30. [CrossRef]

33. Hefti, F.F. Requirements for a lead compound to become a clinical candidate. BMC Neurosci. 2008, 9, S7. [CrossRef]

34. Thangam, T.S.; Kathiresan, K. Mosquito larvicidal effect of seaweed extracts. Bot. Mar. 1991, 34, 433-435. [CrossRef]

35. Ravikumar, S.; Ali, M.S.; Beula, J.M. Mosquito larvicidal efficacy of seaweed extracts against dengue vector of Aedes aegypti. Asian Pac. J. Trop Biomed. 2011, 1, S143-S146.

36. Manilal, A.; Thajuddin, N.; Selvin, J.; Idhayadhulla, A.; Kumar, R.S.; Sujith, S. In vitro mosquito larvicidal activity of marine algae against the human vectors, Culex quinquefasciatus (Say) and Aedes aegypti (Linnaeus) (Diptera: Culicidae). Int. J. Zool. Res. 2011, 7, 272-278. [CrossRef]

37. Birrell, C.L.; McCook, L.J.; Willis, B.L.; Harrington, L. Chemical effects of macroalgae on larval settlement of the broadcast spawning coral Acropora millepora. Mar. Ecol. Prog. Ser. 2008, 362, 129-137. [CrossRef]

38. Brock, E.; Nylund, G.M.; Pavia, H. Chemical inhibition of barnacle larval settlement by the brown alga Fucus vesiculosus. Mar. Ecol. Prog. Ser. 2007, 337, 165-174. [CrossRef]

39. Lau, S.C.K.; Qian, P.Y. Phlorotannins and related compounds as larval settlement inhibitors of the tube-building polychaete Hydroides elegans. Mar. Ecol. Prog. Ser. 1997, 159, 219-227. [CrossRef]

40. Tsukamoto, S.; Hirota, H.; Kato, H.; Fusetani, N. Phlorotannins and Sulfoquinovosyl Diacylglycerols: Promoters of larval metamorphosis in ascidians, isolated from the brown alga Sargassum thunbergii. Fish. Sci. 1994, 60, 319-321. [CrossRef] 
41. Arias, J.R.; Mulla, M.S. Morphogenetic aberrations induced by a juvenile hormone analogue in the mosquito Culex tarsalis (Diptera: Culicidae). J. Med. Entomol. 1975, 12, 309-318. [CrossRef] [PubMed]

42. Kumar, S.; Singh, A.P.; Nair, G.; Batra, S.; Seth, A.; Wahab, N.; Warikoo, R. Impact of Parthenium hysterophorus leaf extracts on the fecundity, fertility and behavioural response of Aedes aegypti L. Parasitol. Res. 2011, 108, 853-859. [CrossRef] [PubMed]

43. Asha, A.; Rathi, J.M.; Raja, D.P.; Sahayaraj, K. Biocidal activity of two marine green algal extracts against third instar nymph of Dysdercus cingulatus (Fab.) (Hemiptera: Pyrrhocoridae). J. Biopest. 2012, 5, 129-134.

44. Nathan, S.S.; Choi, M.Y.; Paik, C.H.; Seo, H.Y.; Kalaivani, K.; Kim, J.D. Effect of azadirachtin on acetylcholinesterase (AChE) activity and histology of the brown planthopper Nilaparvata lugens (Stål). Ecotoxicol. Environ. Saf. 2008, 70, 244-250. [CrossRef]

45. Kukel, C.F.; Jennings, K.R. Delphinium alkaloids as inhibitors of alpha-bungarotoxin binding to rat and insect neural membranes. Can. J. Physiol. Pharmacol. 1994, 72, 104-107. [CrossRef]

46. Machu, L.; Mišurcová, L.; Ambrozova, J.V.; Orsavová, J.; Mlcek, J.; Sochor, J.; Jurikova, T. Phenolic Content and Antioxidant Capacity in Algal Food Products. Molecules 2015, 20, 1118-1133. [CrossRef]

47. Imbs, T.I.; Zvyagintseva, T.N. Phlorotannins are polyphenolic metabolites of brown algae. Russ. J. Mar. Biol. 2018, 44, 217-227. [CrossRef]

48. Aminina, N.M.; Vishnevskaya, T.I.; Karaulova, E.P.; Epur, N.V.; Yakush, E.V. Prospects for the Use of Commercial and Potentially Commercial Brown Algae of the Far Eastern Seas as a Source of Polyphenols. Russ. J. Mar. Biol. 2020, 46, 34-41. [CrossRef]

49. Aminina, N.M.; Vishnevskaya, T.I.; Karaulova, E.P.; Yakush, E.V. Content of polyphenols and antioxidant activity of extracts from certain species of seaweeds. TINRO News 2017, 189, 184-191.

50. Moizer, E.B.; Skerget, M.; Knez, S.; Epur, N.V.; Yakush, E.V. Polyphenols: Extraction methods, antioxidative action, bioavailability and anticancerogenic effects. Molecules 2016, 21,901.

51. Puspita, M.; Déniel, M.; Widowati, I.; Radjasa, O.K.; Douzenel, P.; Marty, C.; Vandanjon, L.; Bedoux, G.; Bourgougnon, N. Total phenolic content and biological activities of enzymatic extracts from Sargassum muticum (Yendo) Fensholt. Environ. Biol. Fishes 2017, 29, 2521-2537. [CrossRef]

52. O'Sullivan, A.M.; O'Callaghan, Y.C.; O'Grady, M.N.; Queguineur, B.; Hanniffy, D.; Troy, D.J.; Kerry, J.P.; O’Brien, N.M. In vitro and cellular antioxidant activities of seaweed extracts prepared from five brown seaweeds harvested in spring from the West Coast of Ireland. Food Chem. 2011, 126, 1064-1070. [CrossRef]

53. Quéguineur, B.; Goya, L.; Ramos, S.; Martín, M.A.; Mateos, R.; Guiry, M.D.; Bravo, L. Effect of phlorotannin-rich extracts of Ascophyllum nodosum and Himanthalia elongata (phaeophyceae) on cellular oxidative markers in human HepG2 cells. J. Appl. Phycol. 2013, 25, 1-11. [CrossRef]

54. Nagayama, K.; Shibata, T.; Fujimoto, K.; Honjo, T.; Nakamura, T. Algicidal effect of phlorotannins from the brown alga Ecklonia kurome on red tide microalgae. Aquaculture 2003, 218, 601-611. [CrossRef]

55. Zou, Y.; Qian, Z.J.; Li, Y.; Kim, M.M.; Lee, S.H.; Kim, S.K. Antioxidant effects of phlorotannins isolated from Ishige okamurae in free radical mediated oxidative systems. J. Agric. Food Chem. 2008, 56, 7001-7009. [CrossRef] [PubMed]

56. Rajbhar, K.; Dawda, H.; Mucundan, U. Polyphenols: Methods of extraction. Sci. Rev. Chem. Commun. 2015, 5, 1-6.

57. Paradis, M.E.; Couture, P.; Lamarche, B. A randomised crossover placebo-controlled trial investigating the effect of brown seaweed (Ascophyllum nodosum and Fucus vesiculosus) on postchallenge plasma glucose and insulin levels in men and women. Appl. Physiol. Nutr. Metab. 2011, 36, 913-919. [CrossRef]

58. Baldrick, F.R.; McFadden, K.; Ibars, M.; Sung, C.; Moffatt, T.; Megarry, K.; Thomas, K.; Mitchell, P.; Wallace, J.M.W.; Pourshahidi, L.K.; et al. Impact of a (poly)phenol-rich extract from the brown algae Ascophyllum nodosum on DNA damage and antioxidant activity in an overweight or obese population: A randomized controlled trial. Am. J. Clin. Nutr. 2018, 108, 688-700. [CrossRef]

59. Shin, H.C.; Kim, S.H.; Park, Y.; Lee, B.H.; Hwang, H.J. Effects of 12-week oral supplementation of Ecklonia cava polyphenols on anthropometric and blood lipid parameters in overweight korean individuals: A double-blind randomized clinical trial. Phytother. Res. 2012, 26, 363-368. [CrossRef]

60. Negara, B.F.S.P.; Sohn, J.H.; Kim, J.S.; Choi, J.S. Effects of phlorotannins on organisms: Focus on the safety, toxicity, and availability of phlorotannins. Foods 2021, 10, 452. [CrossRef]

61. Um, M.Y.; Kim, J.Y.; Han, J.K.; Kim, J.; Yang, H.; Yoon, M.; Kim, J.; Kang, S.W.; Cho, S. Phlorotannin supplement decreases wake after sleep onset in adults with self-reported sleep disturbance: A randomized, controlled, double-blind clinical and polysomnographic study. Phytother. Res. 2018, 32, 698-704. [CrossRef]

62. Cho, J.Y.; Kwon, E.H.; Choi, J.S.; Hong, S.Y.; Shin, H.W.; Hong, Y.K. Antifouling activity of seaweed extracts on the green alga Enteromorpha prolifera and the mussel Mytilus edulis. J. Appl. Phycol. 2001, 13, 117-125.

63. Liberati, A.; Altman, D.G.; Tetzlaff, J.; Mulrow, C.; Gøtzsche, P.C.; Ioannidis, J.P.; Clarke, M.; Devereaux, P.J.; Kleijnen, J.; Moher, D. The PRISMA statement for reporting systematic reviews and meta-analyses of studies that evaluate health care interventions: Explanation and elaboration. PLoS Med. 2009, 6, e1000100. [CrossRef] 